\title{
EFFECT OF TEMPERATURE AND AIR RECIRCULATING RATE ON THE WEIGHT LOSSES OF MINT UNDER HYBRID SOLAR DRYING CONDITIONS
}

\author{
Mahmmoud M. El-Kashoty ${ }^{1}$, El-Sayed G. Khater ${ }^{2 *^{*}}$, Adel H. Bahnasawy ${ }^{3}$ and \\ Khaled S. Nagy ${ }^{4}$
}

${ }^{1}$ PhD. Stud., Ag. Eng. Dept., Fac. of Ag., Benha U., Egypt.

${ }^{2}$ Assoc. Prof. of Ag. Eng., Fac. of Ag., Benha U., Egypt.

${ }^{3}$ Prof. of Ag. Eng., Fac. of Ag., Benha U., Egypt.

${ }^{4}$ Head of Res., Food Tech. Res. Inst., Ag. Res. Center, Giza, Egypt.

*alsayed.khater@fagr.bu.edu.eg

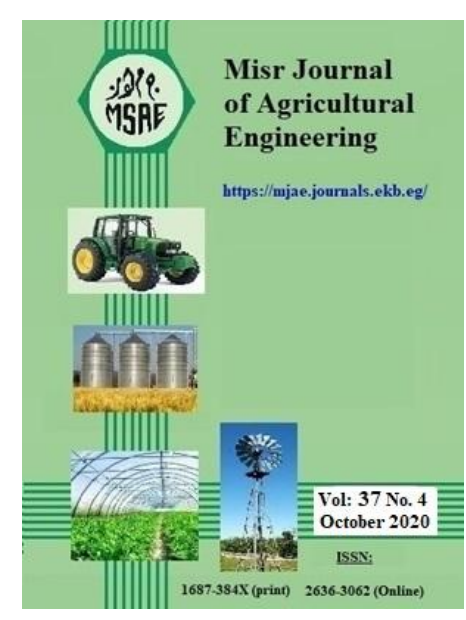

(C) Misr J. Ag. Eng. (MJAE)

Keywords:

Mint, weight loss, moisture content, drying rate, costs

\section{ABSTRACT}

The main aim of this study is to study the effect of drying temperature and air recirculation percentages on the weight losses of mint, drying time, final moisture content and drying rate. Fresh basil was dried using different drying temperatures (50, 55 and $\left.60^{\circ} \mathrm{C}\right)$ and different air recirculating percentages $(70,80$ and $90 \%)$. Air temperature on the drying chamber, Weight losses, moisture content and drying rate were recorded. The obtained results indicated that the air temperature of the drying chamber ranged from 20 to 50,13 to 55 and 18 to $60^{\circ} \mathrm{C}$ for 50,55 and 60 ${ }^{\circ} \mathrm{C}$ drying temperature, respectively. The accumulated weight loss of mint leaves increased from 79.93 to 80.10, 79.99 to 80.15 and 80.05 to $80.29 \%$, when the drying temperature increased from 50 to $60{ }^{\circ} \mathrm{C}$, respectively, for 70,80 and $90 \%$ air recirculating. The moisture content of mint leaves ranged from 2.78 to 402.01, 0.80 to 404.02 and 1.61 to $408.13 \%$ d.b. for 50,55 and $60{ }^{\circ} \mathrm{C}$ drying temperature, respectively. The drying rate of mint leaves decreases with increasing drying temperature and air recirculating percentage. The total costs of dried mint decreased from 8.60 to 7.44, 9.73 to 8.03 and 10.91 to 8.85 L.E kg-1 of mint, when the air recirculating percentage increased from 70 to $90 \%$, respectively at 50, 55 and $60^{\circ} \mathrm{C}$ drying temperature.

\section{INTRODUCTION}

$\mathrm{H}$ erbal plants cultivated in all over the world particularly in Egypt for both local consumption and export. Mint (Mentha spicata L.) is one of the most important medicinal and aromatic plants throughout the world. Mint is very popular in Mediterranean regions and represent a dominant part of the vegetation as a member of the Labiatae Family. The main component on mint is essential oil, its yield ranged from $0.62-1.70$

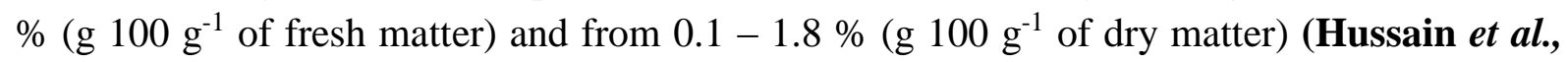
2010). 
Drying is the most common and effective method that increases the shelf life of herbs which inhibit the microorganisms growth and preventing some biochemical reactions that may alter the organoleptic and nutritional characteristics of the dried leaf. However, drying must be performed carefully in order to preserve the aroma, appearance and nutritional characteristics of the raw herbs (Crivelli $\boldsymbol{e t}$ al., 2002 and Khater $\boldsymbol{e t}$ al., 2019). The drying may cause losses in volatilities or formation of new volatilities as a result of oxidation reactions, esterification reactions (Diaz-Maroto et al., 2002).

Solar drying systems must be properly designed in order to meet particular drying requirements of specific products and to give satisfactory performance with respect to energy requirements. Designers should investigate the basic parameters namely dimensions, temperature, relative humidity, airflow rate and the characteristics of products to be dried. However, full scale experiments for different products, drying seasons, and system configurations are sometimes costly and not possible. The development of a simulation model is a valuable tool for predicting of the performance of solar drying systems. Again, simulation of solar drying is essential to optimize the dimensions of solar drying systems and the optimization technique can be used for optimal design of solar drying systems (Bala, 1998).

Hybrid solar dryer is a continued drying method in off sun shine hours by back up another source of heat energy or storage heat energy. For that reason, drying is completed without stopping and product is saved without spoilage by microbial infestation through adverse weather or off sunshine hours (Hossain et al., 2008). The worthy performance was remarked after the heat supply is added to the solar dryer through the time of low radiation (Bennamoun and Belhamri, 2003). Changing attribute of solar radiation make storage indispensable for continuous the process of drying food (Miller, 1983). Storage and supplementary source could be used to assess adjustment of solar energy to achieve the drying process temperature (Singh et al., 1983).

Ali et al. (2014) studied the influence of different drying air temperatures $\left(40,50\right.$ and $\left.60^{\circ} \mathrm{C}\right)$ on drying rate. The initial drying rate was very high at all drying temperatures because high heat was supplied at high temperature due to which more evaporation took place. The drying process at all three temperatures, the drying rate decreased continuously and falling rate was not observed at any temperature, the drying time for oven $50{ }^{\circ} \mathrm{C}$ and oven $60{ }^{\circ} \mathrm{C}$ up to the constant moisture reading could be shortened by $28.12 \%$ and $75 \%$ respectively when compared to oven at $40{ }^{\circ} \mathrm{C}$. The total time taken by moringa leaves to reach moisture contents of $4.77,3.02$ and $3.02 \%$ at temperatures of 40,50 and $60{ }^{\circ} \mathrm{C}$ were $8,5.75$ and $2 \mathrm{~h}$ respectively. The results further indicated that all three oven temperatures able to reduce moringa leaves temperature less than $5 \%$ that is favorable for further processing.

Temperature and air flow rate during are the most important factors affecting the product quality and shelf life after drying, therefore, the main aim of this work is to study the effect of drying temperature and air recirculation percentages on the weight losses of mint, drying time, final moisture content and energy consumption.

\section{MATERIALS AND METHODS}

The experiment was carried out at Agricultural and Bio-Systems Engineering Department, Faculty of Agriculture Moshtohor, Benha University, Egypt (latitude $30^{\circ} 21^{`} \mathrm{~N}$ and $31^{\circ} 13^{`} \mathrm{E}$ ). During the period of January and February, 2020 season. 


\subsection{Materials:}

The fresh mint was brought from the Faculty of Agriculture Farm, Moshtohor, Benha University after harvesting for primary analysis.

\subsubsection{Drying system description:}

Figure (1) illustrates the solar drying system description. It shows the system which consists of solar collector, drying chamber, trays, blower and burner.

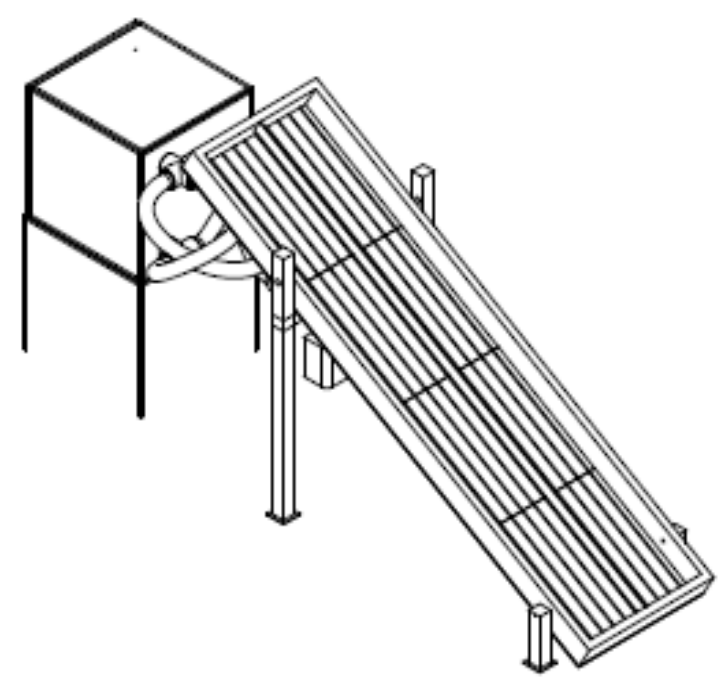

Isometric

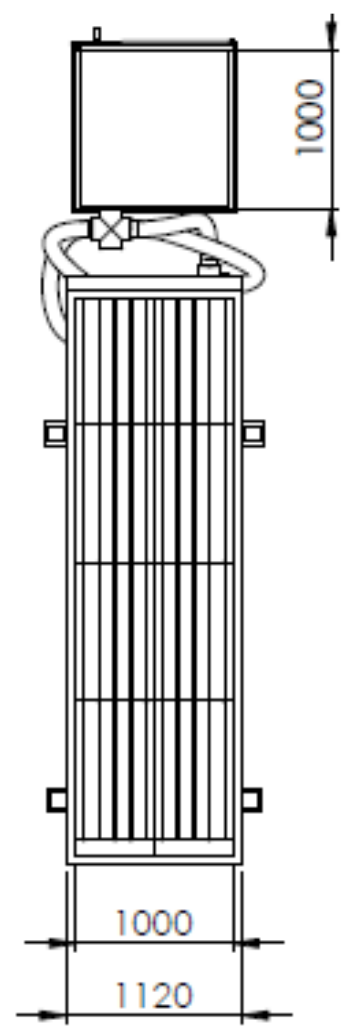

Top View

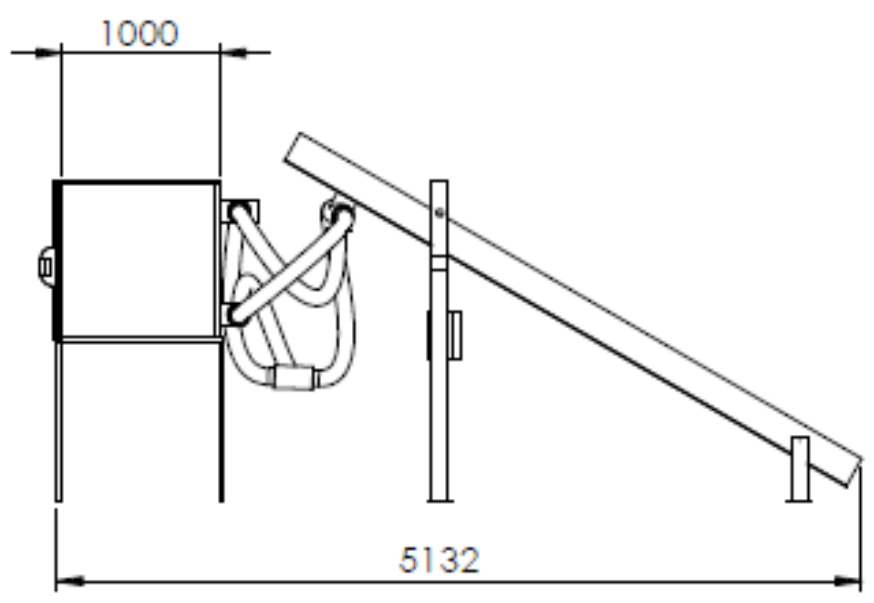

Left View

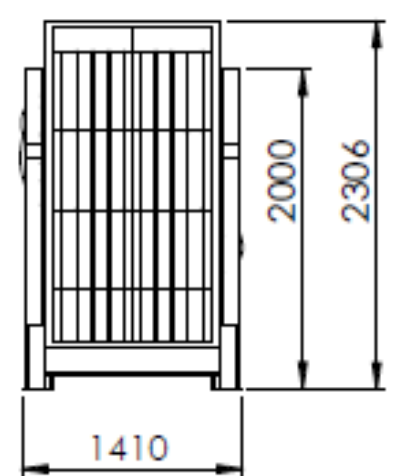

Front View

Figure (1): Elevation, plan and side view for the solar dryer. 


\section{1- The solar collector:}

The solar collector consists of three major components, namely: The glass cover has dimensions of $4.0 \mathrm{~m}$ long, $1.0 \mathrm{~m}$ width and $5.5 \mathrm{~mm}$ thickness. The cover is fixed on a wooden frame with a thickness of $10 \mathrm{~cm}$. It is divided into two lanes, $50 \mathrm{~cm}$ wide each. The absorber plate is made from corrugated black aluminum plate. The insulation is a thermal wool with a $5.0 \mathrm{~cm}$ thickness as shown in figure 2 .

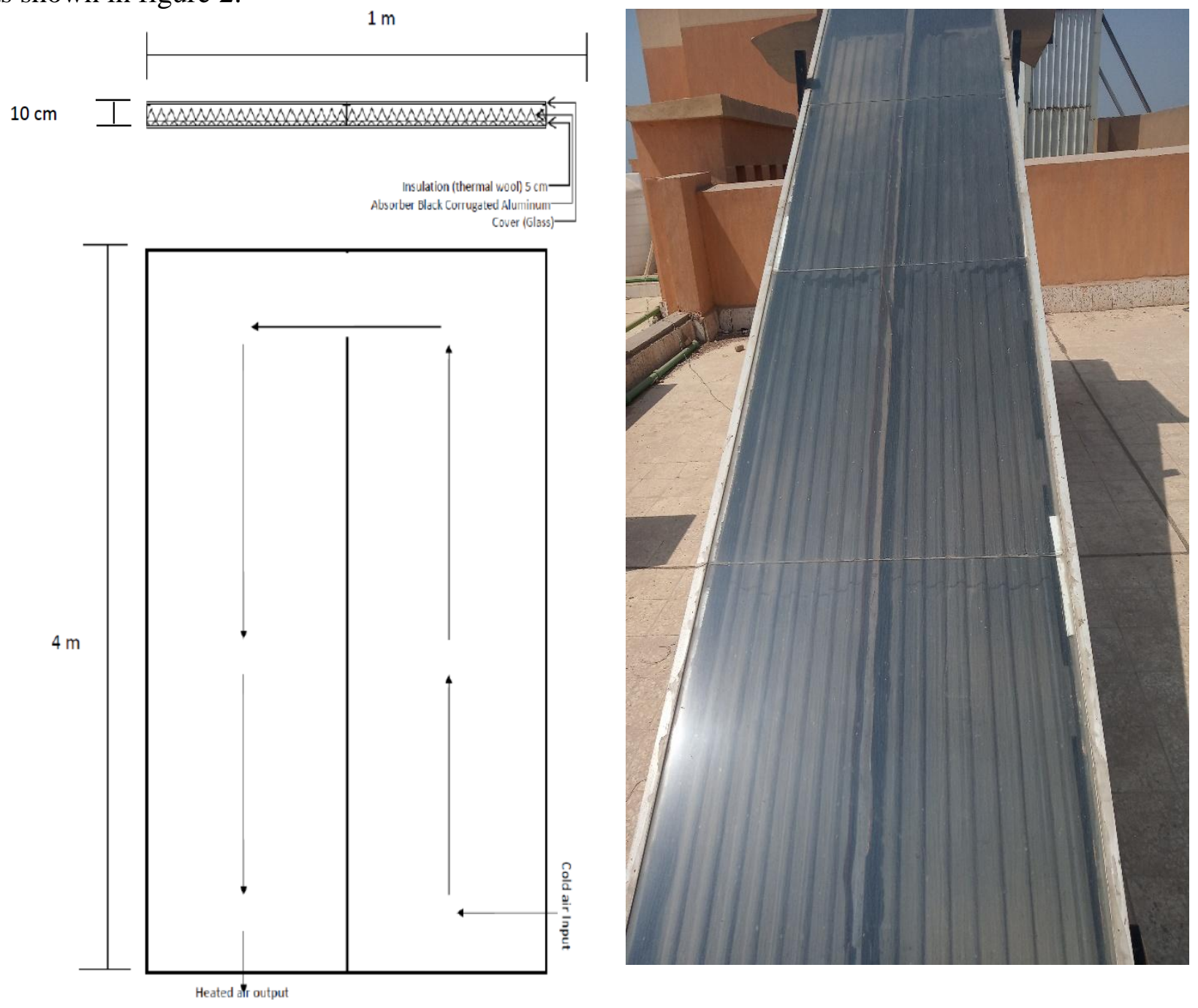

Figure 2: Solar collector.

\section{2- The drying chamber:}

The drying chamber has a length of $1.0 \mathrm{~m}$, width of $0.75 \mathrm{~m}$ and height of $1.0 \mathrm{~m}$. It is made of galvanized steel (5 mm thickness). The inner surface of drying chamber is covered an isolated materials to reduce heat loss from the walls as shown in figure 3.

\section{3- The trays:}

The trays are made of stainless steel and have a length of $0.90 \mathrm{~m}$, width of $0.65 \mathrm{~m}$ and height of $0.25 \mathrm{~m}$. They have perforated bottom which allows heated air to pass through products.

\section{4- The blower:}

Two air blowers were used to force and re-circulate the drying air to the drying chamber (Model C.C.P. Parma - Flow Rate $6.6 \mathrm{~m}^{3} \mathrm{~h}^{-1}$ - RPM 2800 - Power $150 \mathrm{~W}, 220 \mathrm{~V} 50 \mathrm{~Hz}$, Italy). 

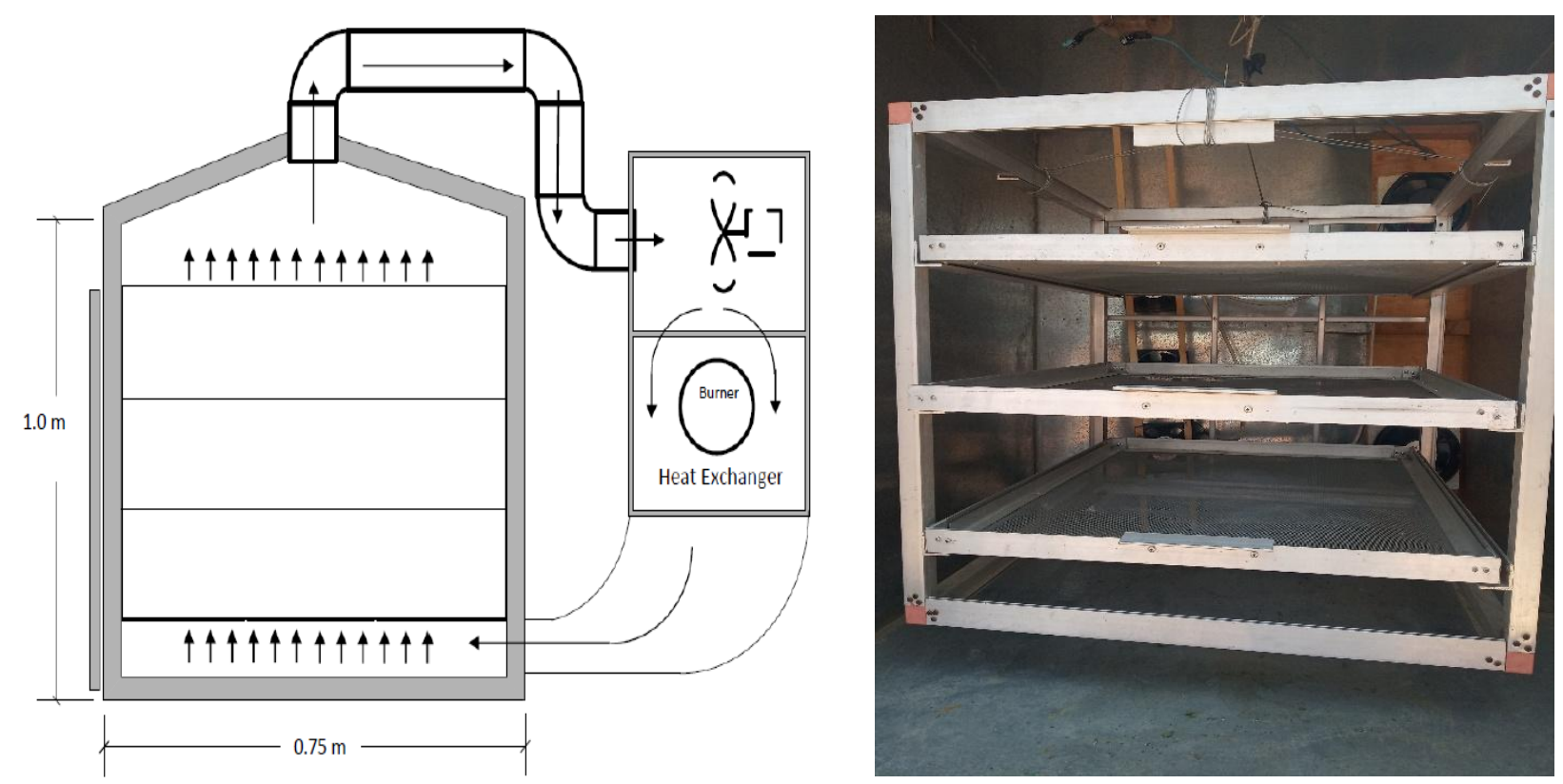

Figure 3: The drying chamber.

\section{5- The burner:}

The dryer uses a chamber burner system in which heat is being produced. The burner incorporates switches with a sparking mechanism that ignites the gas when it is fed from the gas bottle.

\subsection{Methods:}

Mint was cleaned by removing undesired stems and waste materials as shown in the process flow chart (figure 4).

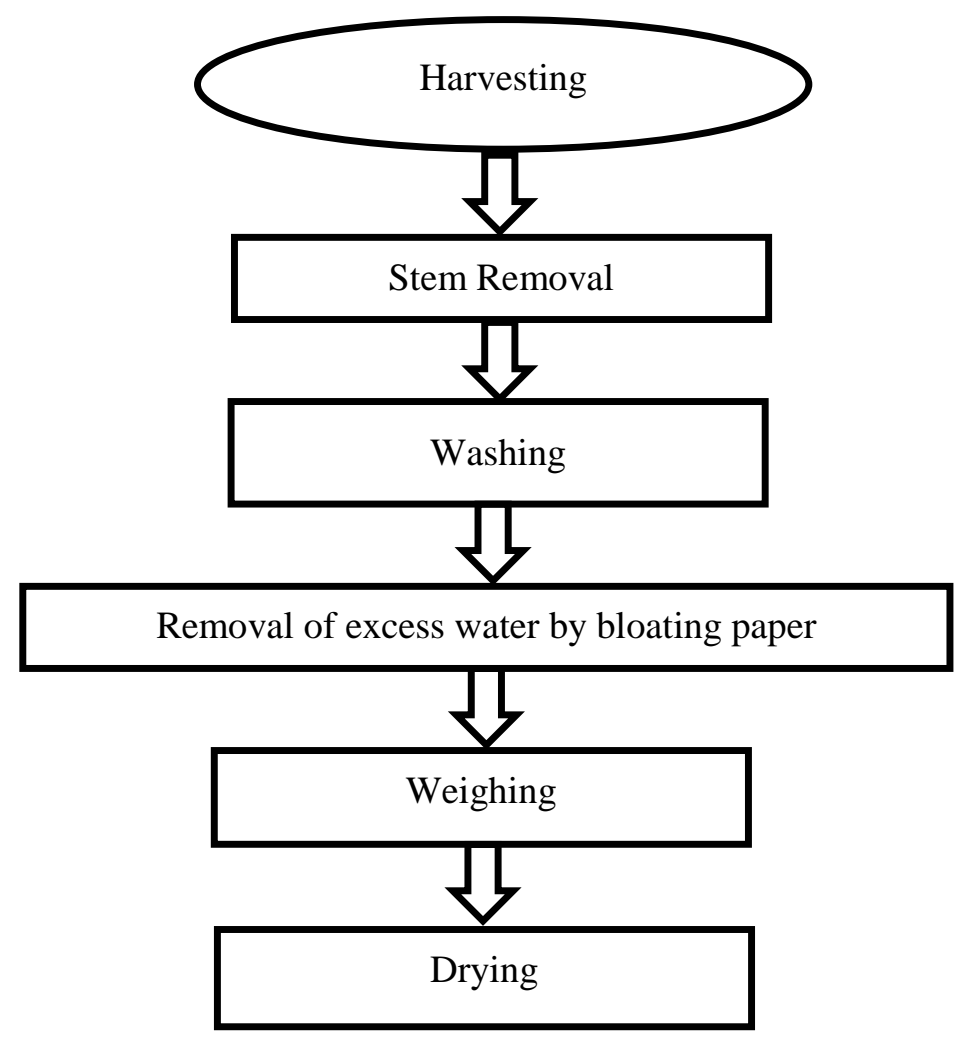

Figure (4): Flow chart of mint processing 


\subsubsection{Treatments:}

In this study, the treatments include: three drying temperatures $\left(50,55\right.$ and $\left.65^{\circ} \mathrm{C}\right)$ and three air recirculation percentages were 70,80 and $90 \%$. The experimental design was a split plot.

\subsubsection{Measurements:}

The mass was measured by electric digital balance (Model HG - 5000 - Range $0-5000 \mathrm{~g} \pm$ $0.01 \mathrm{~g}$, Japan) hourly for solar and hybrid solar drying methods. Temperature and relative humidity were recorded by using a HOBO Data Logger (Model HOBO U12 Temp/RH/Light Range -20 to $70{ }^{\circ} \mathrm{C}$ and 5 to $95 \%$ RH, USA) every hour. Fuel consumption will be recorded for propane fuel sources.

\subsubsection{Calculations:}

\section{- Moisture content:}

Moisture content of the fresh and dried mint leaves was determined using conventional laboratory oven kept at $105{ }^{\circ} \mathrm{C}$ until constant weight was reached. Triplicate determinations were made and the moisture content calculated as the following equation:

$$
M C=\frac{\mathrm{M}_{\text {wet }}-M_{d r y}}{\mathrm{M}_{\mathrm{dry}}} \times 100
$$

Where:

MC is the moisture content, \% d.b.

$\mathrm{M}_{\text {wet }}$ is the wet mass of samples, $\mathrm{g}$

$\mathrm{M}_{\text {dry }}$ is the dry mass of samples, $\mathrm{g}$

\section{- Drying rate:}

The drying rate (DR) of mint was calculated using the following equation:

$$
D R=\frac{\mathrm{M}_{\mathrm{t}+\mathrm{dt}}-M_{t}}{\mathrm{dt}}
$$

Where:

DR is the drying rate, $\left(\mathrm{kg}_{\text {water }} / \mathrm{kg}_{\text {dry base. }} \mathrm{hr}\right)$

$\mathrm{M}_{\mathrm{t}}$ is the moisture content at any time t, \% d.b.

$\mathrm{M}_{\mathrm{t}+\mathrm{dt}}$ is the moisture content at $\mathrm{t}+\mathrm{dt}, \%$ d.b.

\section{- Total Costs}

The cost calculation based on the following parameters was also performed:

- Depreciation costs $\left(D_{c}\right)$ :

$$
\eta=\frac{\mathrm{P}_{\mathrm{d}}-S_{r}}{\mathrm{~L}_{\mathrm{d}}}
$$

Where:

Dc is the depreciation cost, LE year ${ }^{-1}$.

$\mathrm{P}_{\mathrm{d}}$ is the automatic feeder purchase price, $17000 \mathrm{LE}$.

$\mathrm{Sr}$ is the salvage rate $\left(0.1 \mathrm{P}_{\mathrm{d}}\right) \mathrm{LE}$.

Ld is the automatic feeder life, 5 year. 
- Interest costs (In):

$$
I_{n}=\frac{P_{d}+S_{r}}{2} \times \mathrm{i}_{\mathrm{n}}
$$

Where:

$\mathrm{I}_{\mathrm{n}}$ is the interest, LE year ${ }^{-1}$.

$\mathrm{i}_{\mathrm{n}}$ is the interest as compounded annually, decimal. (12\%)

- Shelter, taxes and insurance costs $(\mathrm{Si})$ :

Shelter, taxes and insurance costs were assumed to be $3 \%$ of the purchase price of the automatic feeder $\left(\mathrm{P}_{\mathrm{m}}\right)$.

Then:

$$
\text { Fixed cost }\left(\mathrm{LE} \mathrm{h}^{-1}\right)=\mathrm{Dc}+\mathrm{In}+0.03 \mathrm{Pm} / \text { hour of use per year }
$$

- Repair and maintenance costs $\left(\mathrm{R}_{\mathrm{m}}\right)$ :

$$
\mathrm{R}_{\mathrm{m}}=100 \% \text { deprecation cost / hour of use per year }
$$

- Energy costs (E):

$$
\mathrm{E}=\mathrm{EC} \times \mathrm{EP}
$$

Where:

$\mathrm{E}$ is the energy costs, $\mathrm{LE} \mathrm{h}^{-1}$.

$\mathrm{EC}$ is the electrical energy consumption, $\mathrm{kWh}$.

$\mathrm{EP}$ is the energy price, $0.57 \mathrm{LE} \mathrm{kW}^{-1}$.

-Labor costs (La):

$$
\mathrm{La}=\text { Salary of one worker } \mathrm{x} \text { No. of workers }
$$

Where:

La is the Labor costs, $\mathrm{LE} \mathrm{h}^{-1}$.

Salary of one worker $=10 \mathrm{LE} \mathrm{h}^{-1}$.

No. of workers $=1$

Then:

$$
\begin{aligned}
& \text { Variable costs }\left(\mathrm{LE} \mathrm{h}^{-1}\right)=\mathrm{R}_{\mathrm{m}}+\mathrm{E}+\mathrm{La} \\
& \text { Total costs }\left(\mathrm{LE} \mathrm{h}^{-1}\right)=\text { Fixed costs }\left(\mathrm{LE} \mathrm{h}^{-1}\right)+\text { Variable costs }\left(\mathrm{LE} \mathrm{h}^{-1}\right)
\end{aligned}
$$

\section{RESULTS AND DISCUSSION}

\subsection{Air temperature in the drying chamber:}

Figure (5) shows the effect of different drying temperature $\left(50,55\right.$ and $\left.60{ }^{\circ} \mathrm{C}\right)$ and different air recirculating percentage $(70,80$ and $90 \%)$ on the air temperature of the drying chamber during experimental period. The results indicate that the air temperature of the drying chamber ranged from 24 to 50,24 to 50 and 20 to $50{ }^{\circ} \mathrm{C}$ for 70,80 and $90 \%$ air recirculating, respectively, at $50{ }^{\circ} \mathrm{C}$ drying temperature. The maximum air temperature of the drying chamber was $50{ }^{\circ} \mathrm{C}$ after 135, 135 and $50 \mathrm{~min}$ for 70,80 and $90 \%$ air recirculating, respectively. At $55{ }^{\circ} \mathrm{C}$ drying temperature, the air temperature of the drying chamber ranged from 27 to 55,29 to 55 and 13 to $55{ }^{\circ} \mathrm{C}$ for 70,80 and $90 \%$ air recirculating, respectively. The maximum air temperature inside drying chamber was $55^{\circ} \mathrm{C}$ after 120,105 and $60 \mathrm{~min}$ for 70,80 and $90 \%$ air recirculating, respectively. At $60{ }^{\circ} \mathrm{C}$ drying temperature, the air temperature of the drying chamber ranged from 25 to 60,29 to 60 and 18 to $60{ }^{\circ} \mathrm{C}$ for 70,80 and $90 \%$ air recirculating, respectively. The 
maximum air temperature inside drying chamber was $60{ }^{\circ} \mathrm{C}$ after 120,120 and 45 min for 70 , 80 and $90 \%$ air recirculating, respectively.
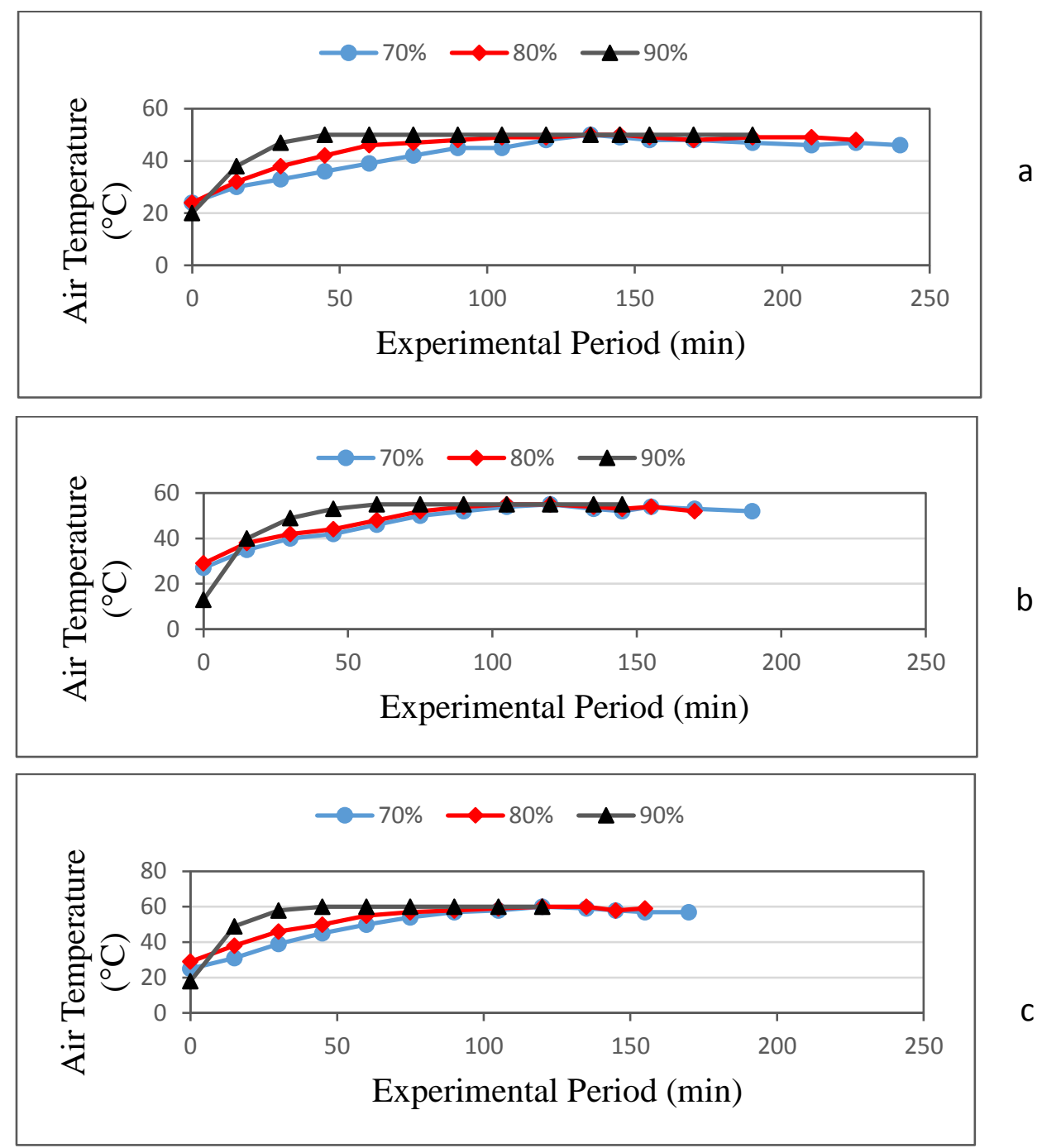

Figure (5): Effect of different drying temperature and air recirculating on the air temperature inside drying chamber during experimental period.

$$
\begin{array}{lll}
\text { a: } 50{ }^{\circ} \mathrm{C} & \text { b: } 55^{\circ} \mathrm{C} & \text { c: } 60{ }^{\circ} \mathrm{C}
\end{array}
$$

\subsection{Weight loss:}

Figure (6) shows the accumulated weight loss of mint leaves that dried under different drying temperatures $\left(50,55\right.$ and $\left.60{ }^{\circ} \mathrm{C}\right)$ and different air recirculating percentage $(70,80$ and 90\%) during experimental period. The results indicate that the accumulated weight loss of mint leaves increases with increasing drying temperature and air recirculating during drying period. It could be seen that the accumulated weight loss of mint leaves increased from 7.52 to $79.98,9.25$ to 79.98 and 10.59 to $80.10 \%$, when the drying period increased from 15 to 240,15 to 225 and 15 to $190 \mathrm{~min}$, respectively, for 70,80 and $90 \%$ air recirculating at $50{ }^{\circ} \mathrm{C}$ drying temperature. At $55{ }^{\circ} \mathrm{C}$ drying temperature, the accumulated weight loss of mint leaves increased from 9.59 to $79.99,10.82$ to 80.09 and 12.18 to $80.15 \%$, when the drying period increased from 15 to 190, 15 to 170 and 15 to $145 \mathrm{~min}$, respectively, for 70,80 and $90 \%$ air recirculating. At $60{ }^{\circ} \mathrm{C}$ drying temperature, the accumulated weight loss of mint leaves increased from 11.16 to 80.05, 
12.62 to 80.16 and 13.75 to $80.29 \%$, when the drying period increased from 15 to 170,15 to 155 and 15 to $120 \mathrm{~min}$, respectively, for 70,80 and $90 \%$ air recirculating.
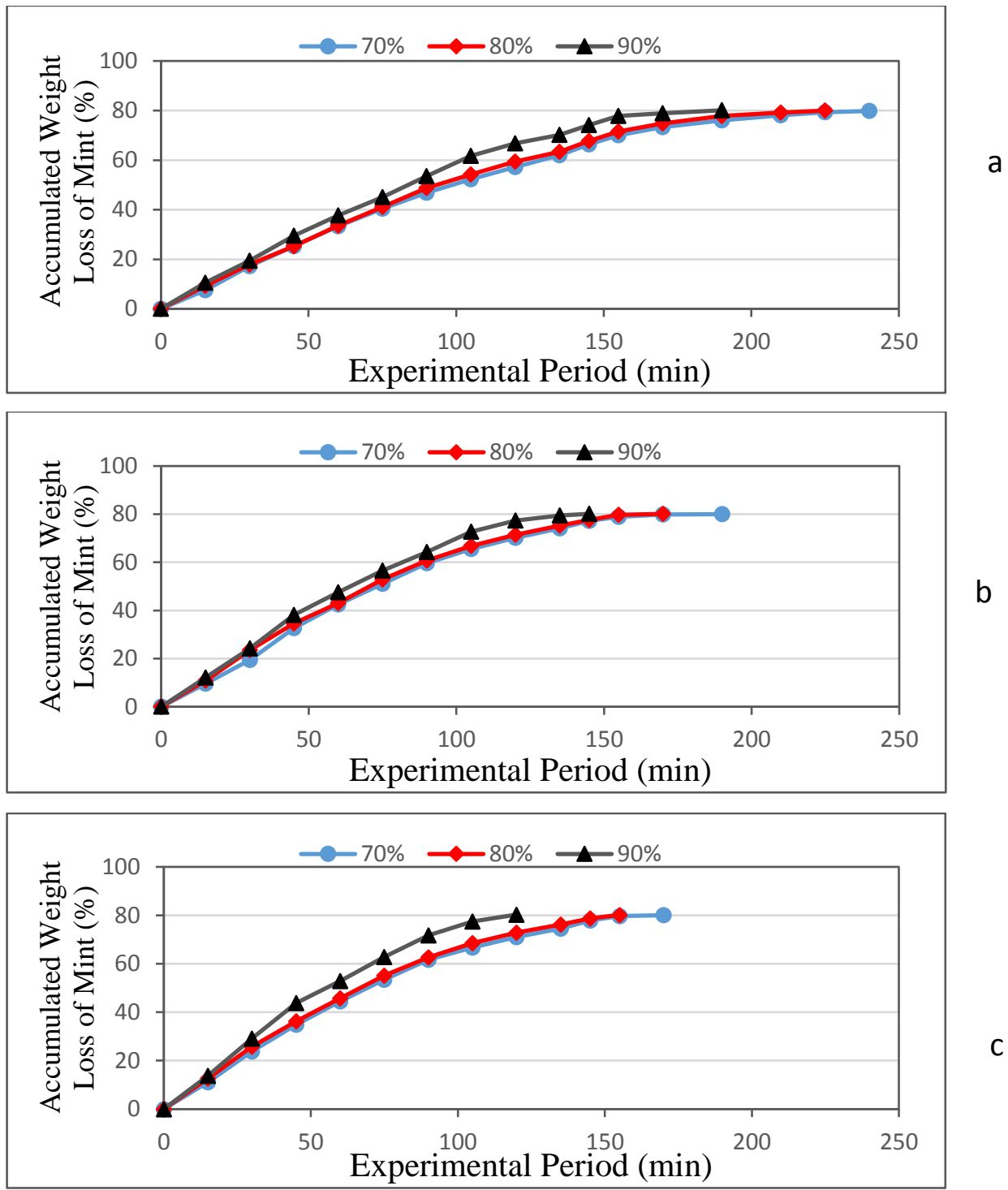

Figure (6): The accumulated weight loss of mint leaves at different drying temperatures and different air recirculating during experimental period.

$$
\text { a: } 50{ }^{\circ} \mathrm{C} \quad \text { b: } 55^{\circ} \mathrm{C} \quad \text { c: } 60{ }^{\circ} \mathrm{C}
$$

The results indicate that the accumulated weight loss of mint leaves increases with increasing drying temperature, it could be seen that the accumulated weight loss of mint leaves increased from 79.93 to $80.10,79.99$ to 80.15 and 80.05 to $80.29 \%$, when the drying temperature increased from 50 to $60{ }^{\circ} \mathrm{C}$, respectively, for 70,80 and $90 \%$ air recirculating. These results agreed with those obtained by Doymaz (2006) whose found the weight loss increases with increasing drying temperature.

The results also indicate that the shorter drying period $(120 \mathrm{~min})$ was occurred under the $90 \%$ air recirculating due to the higher temperature $\left(60{ }^{\circ} \mathrm{C}\right)$. Meanwhile, the longer drying period (240 min) was occurred under the $70 \%$ air recirculating due to the lower temperature $\left(50{ }^{\circ} \mathrm{C}\right)$. The trend of these results agreed with those obtained by Khater and Bahnasawy (2017). 
Multiple regression analysis was carried out to obtain a relationship between the accumulated weight loss as dependent variable and different both of drying temperature, air recirculating and experimental period as independent variables. The best fit for this relationship is presented in the following equation:-

$$
\begin{array}{lll}
\text { For } 50{ }^{\circ} \mathrm{C} & W L=-19.79+0.36 A R+0.38 t & \mathrm{R}^{2}=0.94 \\
\text { For } 55{ }^{\circ} \mathrm{C} & W L=-21.80+0.47 A R+0.41 t & \mathrm{R}^{2}=0.92 \\
\text { For } 60{ }^{\circ} \mathrm{C} & W L=-31.78+0.50 A R+0.55 t & \mathrm{R}^{2}=0.90
\end{array}
$$

Where:

WL is the accumulated weight loss, $\%$

$\mathrm{AR}$ is the air recirculating percentage, $\%$

$\mathrm{t}$ is the experimental period, $\min$

This equation could be applied in the range of 70 to $90 \%$ air recirculating percentage and from 1 to $240 \mathrm{~min}$ of experimental period.

\subsection{Moisture content:}

Figure (7) shows the moisture content of mint leaves that dried under different drying temperatures $\left(50,55\right.$ and $\left.60{ }^{\circ} \mathrm{C}\right)$ and different air recirculating percentage $(70,80$ and 90\%) during experimental period. The results indicate that the moisture content of mint leaves decreases with increasing drying temperature and air recirculating during drying period. It could be seen that the moisture content of mint leaves decreased from 396.03 to 2.78, 400.00 to 4.40 and 402.01 to $5.62 \%$ d.b., when the drying period increased from 15 to 240,15 to 225 and 15 to $190 \mathrm{~min}$, respectively, for 70,80 and $90 \%$ air recirculating at $50{ }^{\circ} \mathrm{C}$ drying temperature. At $55{ }^{\circ} \mathrm{C}$ drying temperature, the moisture content of mint leaves decreased from 400.00 to 0.80 , 402.01 to 2.01 and 404.02 to $3.23 \%$ d.b., when the drying period increased from 15 to 190,15 to 170 and 15 to $145 \mathrm{~min}$, respectively, for 70,80 and $90 \%$ air recirculating. At $60{ }^{\circ} \mathrm{C}$ drying temperature, the moisture content of mint leaves decreased from 402.01 to $1.61,404.03$ to 7.26 and 408.13 to $14.23 \%$ d.b., when the drying period increased from 15 to 170,15 to 155 and 15 to $120 \mathrm{~min}$, respectively, for 70,80 and $90 \%$ air recirculating.

The results indicate that the moisture content of mint leaves increases with increasing drying temperature, it could be seen that the moisture content of mint leaves increased from 396.03 to 402.01, 400.00 to 404.02 and 402.01 to $408.13 \%$ d.b., when the drying temperature increased from 50 to $60{ }^{\circ} \mathrm{C}$, respectively, for 70,80 and $90 \%$ air recirculating after $15 \mathrm{~min}$ of drying period. Increased drying temperature and air recirculating further decrease the relative humidity of a product. This can be explained by the fact that increased temperature and hot airflow inside the drying chamber increases mass and heat transfer, leading to sharper drops in moisture content. These results agreed with those obtained by Doymaz (2006) whose found the moisture content increases with increasing drying temperature.

The results indicate that the highest rate of the decrease moisture content of baisl plants (99.80\%) was happened under the $70 \%$ air recirculating due to the higher temperature $\left(55^{\circ} \mathrm{C}\right)$. Meanwhile, the lowest rate of the decrease moisture content of baisl plants (96.51\%) was found 
under the $70 \%$ air recirculating due to the lower temperature $\left(60{ }^{\circ} \mathrm{C}\right)$. The trend of these results agreed with those obtained by Danso-Boateng (2013).
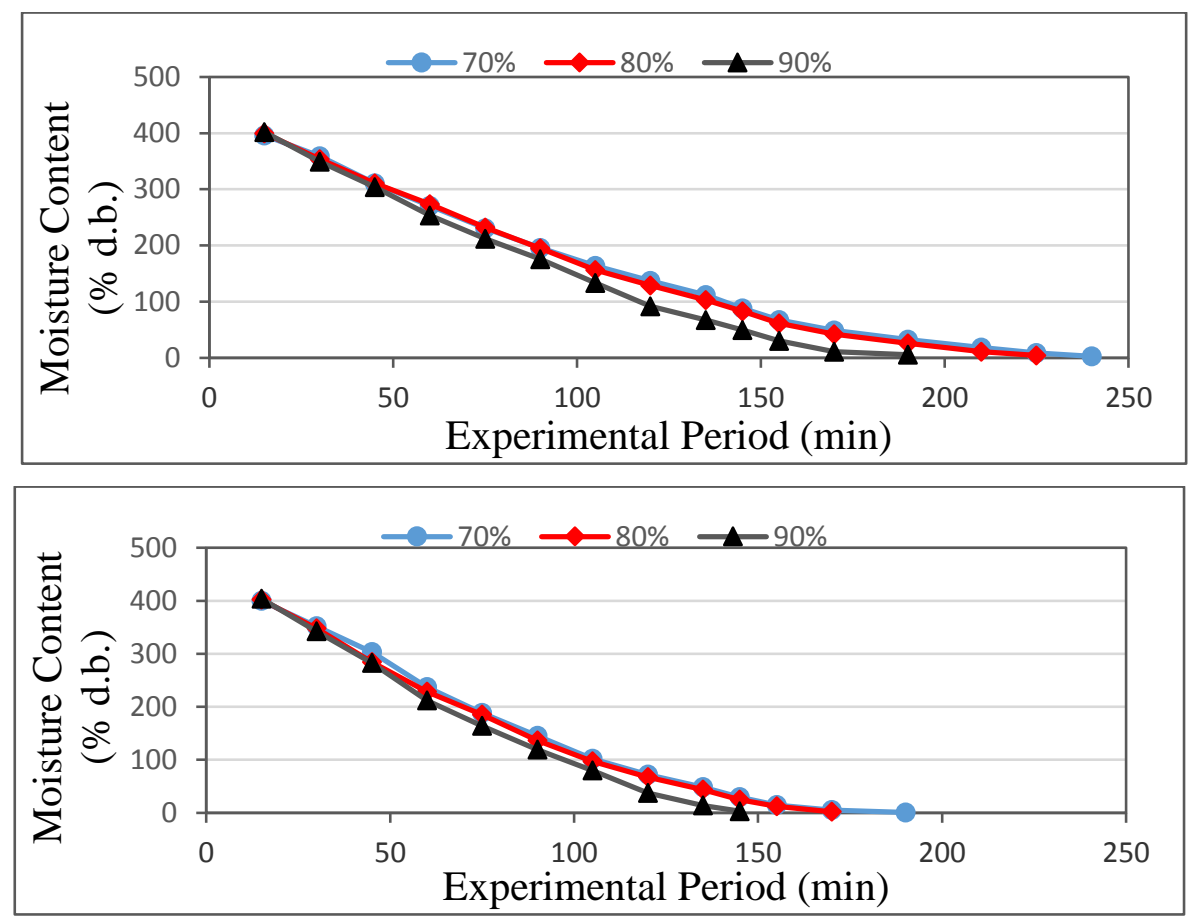

b

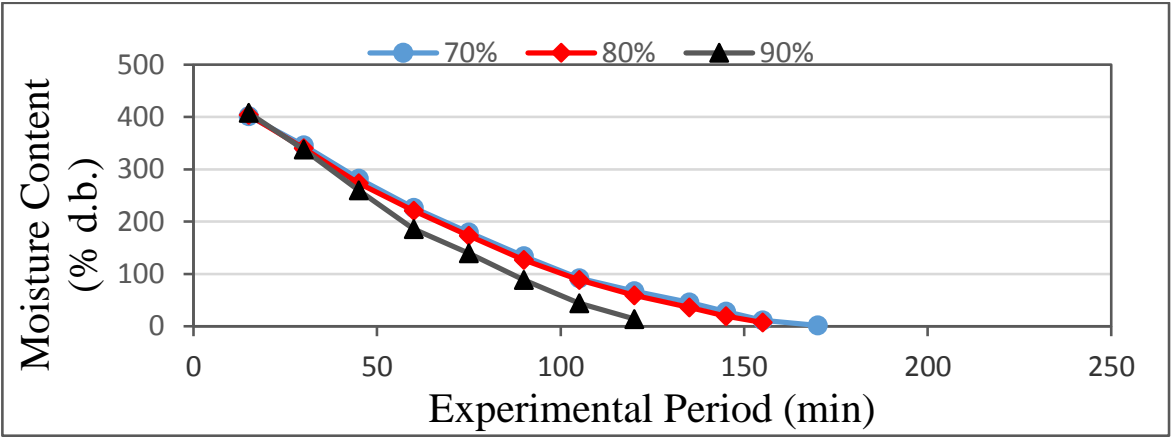

C

Figure (7): The moisture content of mint leaves at different drying temperatures and different air recirculating during experimental period.

$$
\text { a: } 50{ }^{\circ} \mathrm{C} \quad \text { b: } 55^{\circ} \mathrm{C} \quad \text { c: } 60{ }^{\circ} \mathrm{C}
$$

Multiple regression analysis was carried out to obtain a relationship between the accumulated weight loss as dependent variable and different both of drying temperature, air recirculating and experimental period as independent variables. The best fit for this relationship is presented in the following equation:-

$$
\begin{array}{lll}
\text { For } 50{ }^{\circ} \mathrm{C} & M \mathrm{C}=492.66-1.92 A R-1.73 t & \mathrm{R}^{2}=0.95 \\
\text { For } 55^{\circ} \mathrm{C} & \mathrm{MC}=498.88-2.50 A R-1.80 t & \mathrm{R}^{2}=0.93 \\
\text { For } 60^{\circ} \mathrm{C} & M \mathrm{C}=538.89-2.71 A R-2.29 t & \mathrm{R}^{2}=0.92
\end{array}
$$

Where:

$\mathrm{MC}$ is the moisture content, \% d.b.

This equation could be applied in the range of 70 to $90 \%$ air recirculating percentage and from 1 to 240 min of experimental period. 


\subsection{Drying rate:}

Figure (8) shows the drying rate of mint leaves that dried under different drying temperatures $\left(50,55\right.$ and $60{ }^{\circ} \mathrm{C}$ ) and different air recirculating percentage (70, 80 and 90\%) during experimental period. The results indicate that the drying rate of mint leaves decreases with increasing drying temperature and air recirculating during drying period.
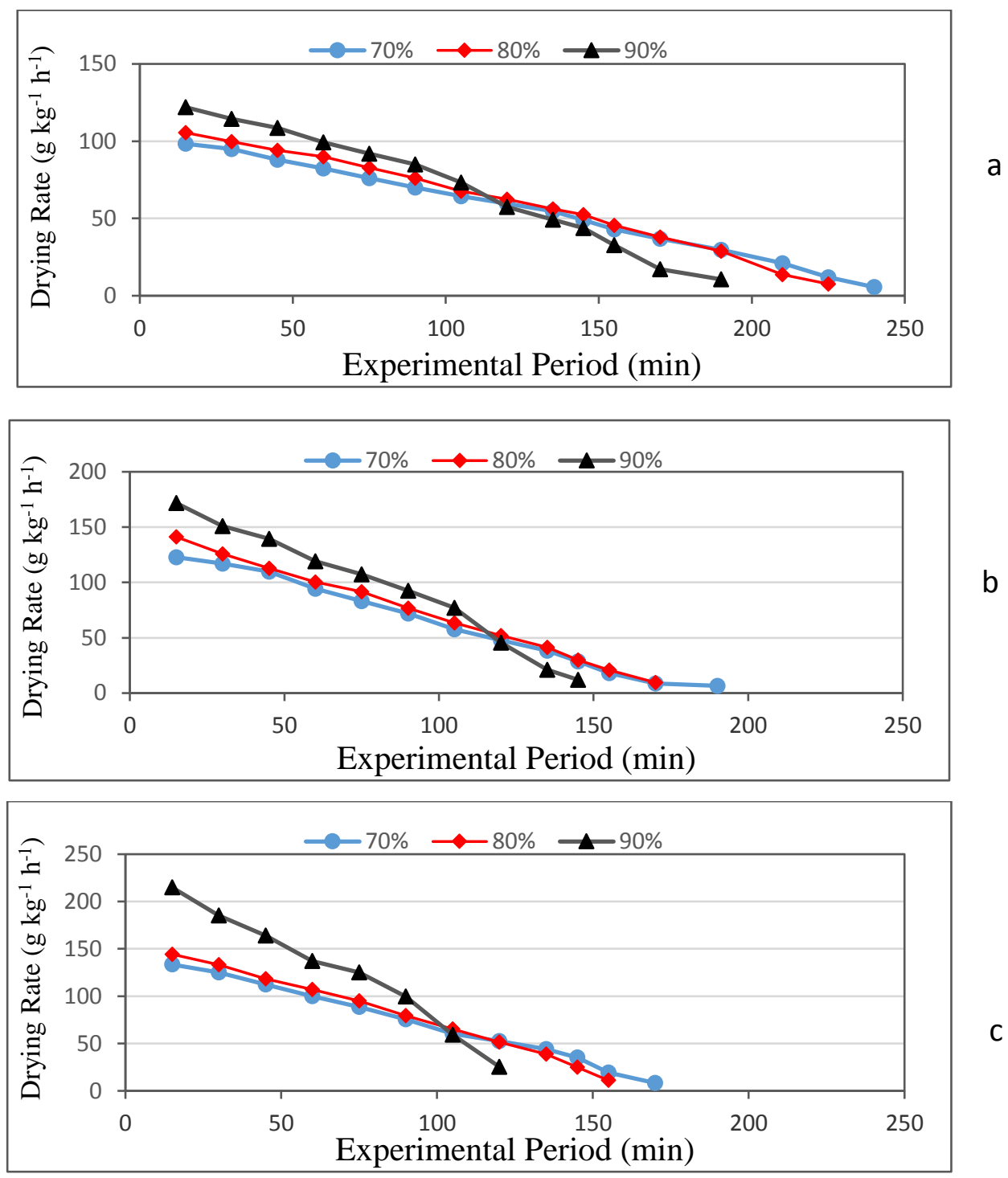

Figure (8): The drying rate of mint leaves at different drying temperatures and different air recirculating during experimental period.

$$
\text { a: } 50{ }^{\circ} \mathrm{C} \quad \text { b: } 55^{\circ} \mathrm{C} \quad \text { c: } 60{ }^{\circ} \mathrm{C}
$$

It could be seen that the drying rate of mint leaves decreased from 98.31 to 5.60, 105.49 to 7.60 and 121.96 to $10.58 \mathrm{~g}_{\text {water }} \mathrm{kg}^{-1} \mathrm{~h}^{-1}$, when the drying period increased from 15 to 240,15 to 225 and 15 to $190 \mathrm{~min}$, respectively, for 70,80 and $90 \%$ air recirculating at $50{ }^{\circ} \mathrm{C}$ drying temperature. At $55^{\circ} \mathrm{C}$ drying temperature, the drying rate of mint leaves decreased from 122.83 to $6.59,141.18$ to 9.54 and 171.77 to $12.04 \mathrm{~g}_{\text {water }} \mathrm{kg}^{-1} \mathrm{~h}^{-1}$, when the drying period increased from 15 to 190,15 to 170 and 15 to $145 \mathrm{~min}$, respectively, for 70,80 and $90 \%$ air recirculating. At $60{ }^{\circ} \mathrm{C}$ drying temperature, the drying rate of mint leaves decreased from 133.47 to 8.26, 
144.28 to 11.03 and 214.86 to $25.37 \mathrm{~g}_{\text {water }} \mathrm{kg}^{-1} \mathrm{~h}^{-1}$, when the drying period increased from 15 to 170,15 to 155 and 15 to $120 \mathrm{~min}$, respectively, for 70,80 and $90 \%$ air recirculating.

The results indicate that the drying rate of mint leaves increases with increasing drying temperature, it could be seen that the drying rate of mint leaves increased from 98.31 to 121.96, 122.83 to 171.77 and 133.47 to $214.86 \mathrm{~g}_{\text {water }} \mathrm{kg}^{-1} \mathrm{~h}^{-1}$, when the drying temperature increased from 50 to $60{ }^{\circ} \mathrm{C}$, respectively, for 70,80 and $90 \%$ air recirculating after $15 \mathrm{~min}$ of drying period. These results agreed with those obtained by Amer et al. (2018).

Multiple regression analysis was carried out to obtain a relationship between the accumulated weight loss as dependent variable and different both of drying temperature, air recirculating and experimental period as independent variables. The best fit for this relationship is presented in the following equation:-

$$
\begin{array}{lll}
\text { For } 50{ }^{\circ} \mathrm{C} & \mathrm{DR}=90.67-0.47 A R+0.25 t & \mathrm{R}^{2}=0.95 \\
\text { For } 55{ }^{\circ} \mathrm{C} & D \mathrm{R}=76.06-0.84 A R+0.84 t & \mathrm{R}^{2}=0.95 \\
\text { For } 60{ }^{\circ} \mathrm{C} & D \mathrm{R}=26.35-0.93 A R+1.66 t & \mathrm{R}^{2}=0.91
\end{array}
$$

Where:

DR is the drying rate, $\mathrm{g}_{\text {water }} \mathrm{kg}^{-1} \mathrm{~h}^{-1}$.

This equation could be applied in the range of 70 to $90 \%$ air recirculating percentage and from 1 to 240 min of experimental period.

\subsection{Total Costs:}

Table (1) shows the total costs of mint leaves that dried under different drying temperatures $\left(50,55\right.$ and $60{ }^{\circ} \mathrm{C}$ ) and different air recirculating percentage (70, 80 and 90\%) during experimental period. The results indicate that the total cost of dried mint increases with increasing drying temperature and decreases with increasing air recirculating percentage. It could be seen that the total costs of dried mint decreased from 8.60 to $7.44,9.73$ to 8.03 and 10.91 to $8.85 \mathrm{~L} . \mathrm{E} \mathrm{kg}{ }^{-1}$ of mint, when the air recirculating percentage increased from 70 to 90 $\%$, respectively at 50,55 and $60{ }^{\circ} \mathrm{C}$ drying temperature.

Table (2): The total costs of dried mint leaves.

\begin{tabular}{|c|c|c|c|}
\hline \multirow{2}{*}{$\begin{array}{c}\text { Drying Temperature, } \\
{ }^{\circ} \mathrm{C}\end{array}$} & 70 & \multicolumn{3}{|c|}{ Air Recirculating Percentage, \% } \\
\cline { 2 - 4 } & \multicolumn{3}{|c|}{ Total Cost, $\mathrm{LE} \mathrm{kg}^{-1}$} \\
\hline 50 & 8.60 & 8.07 & 70 \\
\hline 55 & 9.73 & 8.75 & 8.03 \\
\hline 60 & 10.91 & 9.38 & 8.85 \\
\hline
\end{tabular}

\section{CONCLUSION}

The experiment was carried out to study the effect of drying temperature and air recirculation percentages on the weight losses of mint, drying time, final moisture content and energy consumption. The obtained results can be summarized as follows: 
- The air temperature of the drying chamber ranged from 20 to 50, 13 to 55 and 18 to 60 ${ }^{\circ} \mathrm{C}$ for 50,55 and $60{ }^{\circ} \mathrm{C}$ drying temperature, respectively.

- The accumulated weight loss of mint leaves increased from 79.93 to $80.10,79.99$ to 80.15 and 80.05 to $80.29 \%$, when the drying temperature increased from 50 to $60{ }^{\circ} \mathrm{C}$, respectively, for 70,80 and $90 \%$ air recirculating.

- The moisture content of mint leaves ranged from 2.78 to $402.01,0.80$ to 404.02 and 1.61 to $408.13 \%$ d.b. for 50,55 and $60{ }^{\circ} \mathrm{C}$ drying temperature, respectively.

- $\quad$ The drying rate of mint leaves increased from 98.31 to $121.96,122.83$ to 171.77 and 133.47 to $214.86 \mathrm{~g}_{\text {water }} \mathrm{kg}^{-1} \mathrm{~h}^{-1}$, when the drying temperature increased from 50 to 60 ${ }^{\circ} \mathrm{C}$, respectively, for 70,80 and $90 \%$ air recirculating after $15 \mathrm{~min}$ of drying period.

- $\quad$ The total costs of dried mint decreased from 8.60 to $7.44,9.73$ to 8.03 and 10.91 to 8.85 L.E $\mathrm{kg}^{-1}$ of mint, when the air recirculating percentage increased from 70 to $90 \%$, respectively at 50,55 and $60{ }^{\circ} \mathrm{C}$ drying temperature.

\section{REFERENCES}

Ali, M.A., Yousuf Y.A., Ibrahim M.N. and Basra S.M.A. (2014). Drying kinetics and colour analysis of Moringa Oleifera leaves. Agriculture and Agricultural Sciences Procedia, 2, $394-400$.

Amer, B.M.A., Gottschalk K. and Hossain M.A. (2018). Integrated hybrid solar drying system and its drying kinetics of chamomile. Renewable Energy 121, 539 - 547.

Bala, B.K. (1998). Solar drying systems: simulation and optimization. Udaipur (India): Agrotech Publishing Academy; 1998.

Bennamoun, L. and Belhamri A. (2003). Design and simulation of a solar dryer for agricultural products, J. Food Eng., 59, 259 - 266.

Crivelli, G., Nani R.C. and Di Cesare L.F. (2002). Influence of processing on the quality of dried herbs. Atti VI Giornatescientifiche SOI. Spoleto, 2: 463 - 464.

Diaz-Maroto, M.C., Pérez-Coello M.S. and Cabezudo M.D. (2002). Effect of drying method on the volatilities in bay leaf (Laurusnobilis L.). Journal of Agricultural Food Chemistry, 50: 4520 - 4524.

Doymaz I. (2006). Thin-layer drying behaviour of mint leaves. Journal of Food Engineering, $74,370-375$.

Hossain, M.A., Amer B.M.A. and Gottschalk K. (2008). Hybrid solar dryer for quality dried tomato, Dry. Technol. 26, 1591 - 1601.

Hussain, A.I, Anwar F., Shahid M., Ashraf M. and Przybylski R. (2010). Chemical composition, antioxidant and antimicrobial activities of essential oil of spearmint (Mentha spicata L.) from Pakistan. Journal of Essential Oil Research, 22(1): 78 - 84. 
Khater, E.G., Bahnasawy A.H. (2017). Basil Drying Performance and Quality under Different Drying Systems. $2^{\text {nd }}$ International Sino-Egyptian Congress on Agriculture, Veterinary Sciences and Engineering ( ${ }^{\text {nd }}$ ISEC-AVE), 7 - 10 October, 2017, Egypt.

Khater, E.G., Bahnasawy A.H., Hamouda R.M. (2019). Dehydration of chamomile flowers under different drying conditions. Journal of Food Processing and Technology, 10 (7), 17.

Miller, W.M. (1983). Energy storage via desiccants for food/agricultural applications, Energy Agric. 2 (4), 341 - 354.

Singh, R.K., D.B. Lund and F.H. Buelow (1983). Application of solar energy in food processing. II. Food dehydration, Trans. ASAE 26 (5), 1569 - 1574. 


\section{تأثير درجة الحرارة ودوران الهواء

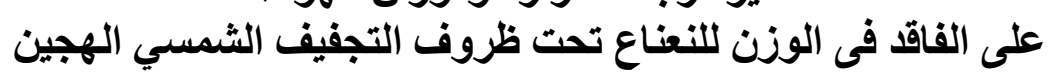

محمود محمد الحسيني القشوطي'، السيد جمعه خاطر ‘، عادل حامد بهنساوي ' و خالد سيد أحمد ناجى؛

طالب دكتور اة - قسم الهندسة الزر اعية ـ كلية الزر اعة بمشتهر - جامعة بنها - مصر.

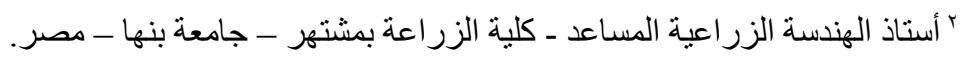

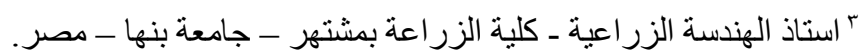

؛ رئيس بحوث معهد بحوث تكنولوجيا الأغذية - مركز البحوث الزراعية بالدقي ـ الجيزة - مصر.

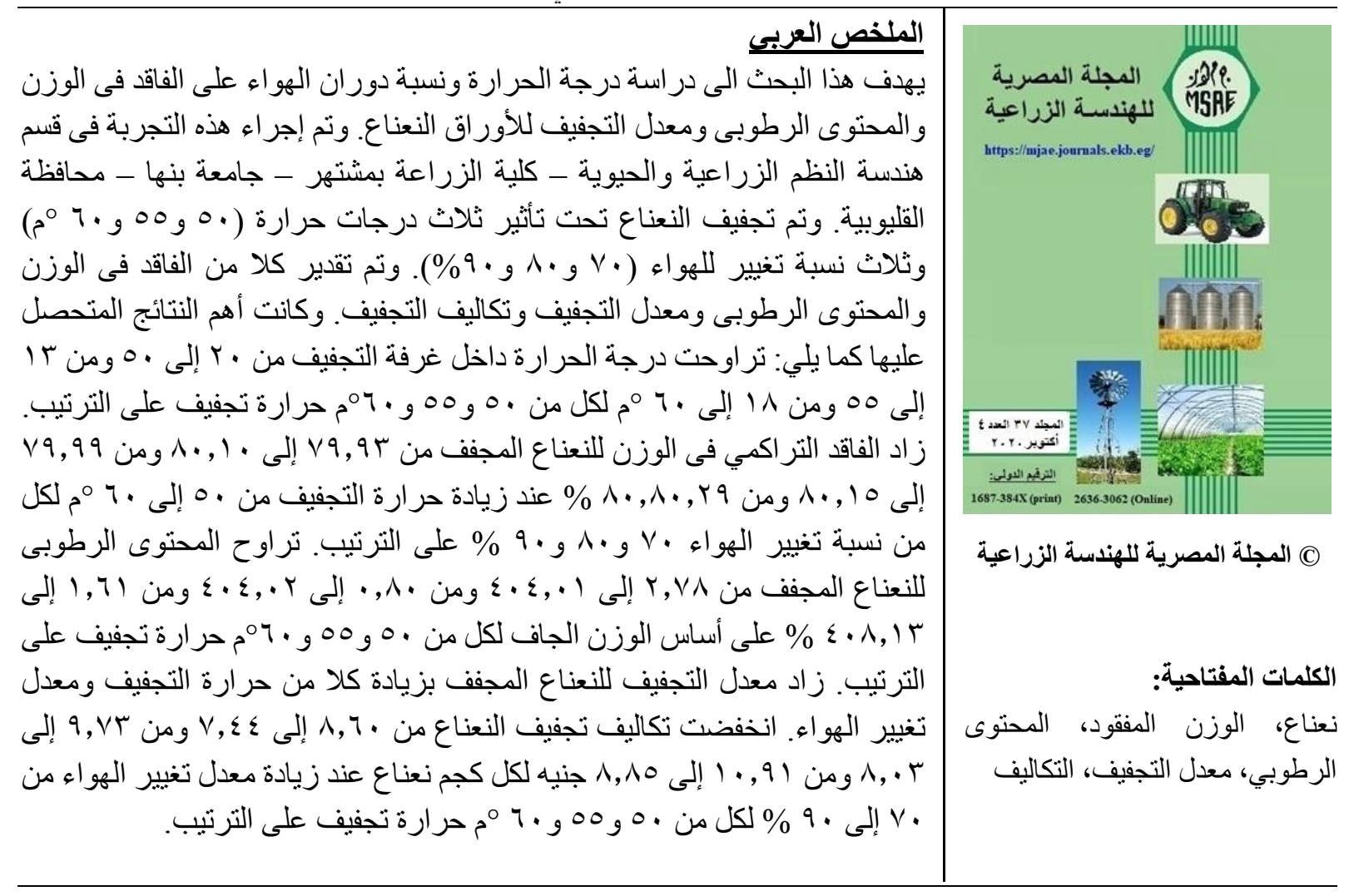

